\title{
The effect of the combination of caffeine and taurine of different concentrations on activated B-cells
}

\author{
Martin Gansel ${ }^{1}$, St. Elisabeth University, Bratislava, Slovakia
}

\begin{abstract}
Caffeinated drinks are popular because of their mood- and performance-enhancing effects. Energy drinks are advertised with these properties, with the content of caffeine and taurine being a central component of these products. However, little is known about the influence of taurine and caffeine on immune cells. This article answers the following research question: "How high is the effect of the combination of caffeine and taurine of different concentrations on activated B-cells". Immunoglobulin production is a measure of B-cell activity. This property is determined in mouse B-cells. For this purpose, these cells are taken from the spleen of mice, induced with CD40/IL4 and the activity is checked with the aid of an immunoglobulin ELISA. Low doses of taurine and caffeine in combination do not cause any significant change in immunoglobulin production, whereas high doses ( 4 or $40 \mathrm{mg} / \mathrm{ml}$ ) lead to cell death.
\end{abstract}

Keywords: Taurine, Activated B-Cells, Effect of caffeine and taurine on activated B-cells

JEL codes: $A 100, A 110$

${ }^{1}$ Doctoral Supervisor: Prof. Dr. Dr. med. Claus Muss, St. Elisabeth University, Bratislava, Slovakia 


\section{Introduction}

\section{Taurine - physiological properties}

Taurine plays an important role as an inhibitory neurotransmitter. It increases the permeability for chloride ions in nerve cells and thereby leads to a hyperpolarization of the synapse membrane. It inhibits the development of an action potential and thus the transmission of stimuli in the central nervous system. However, studies have also shown the possibility that taurine activates the serotonin system. ${ }^{1}$

Taurine is a degradation product of the protein components (amino acids) methionine and cysteine. The human body can establish the compound itself and is not dependent on an external supply. Taurine is found in a variety of foods, most notably fish, meat, and milk. In the body, the substance is found in many types of tissue and fulfills a variety of tasks there. These include, for example, the stabilization of cell membranes and the binding of cell-damaging "free radicals", which corresponds to an antioxidant effect. In addition, taurine is a component of bile acid conjugates and thus involved in fat digestion: It is attached to the bile acids formed in the liver to improve their solubility. Taurine is also involved in the development of the central nervous system and the heart. There are indications of other effects such as anti-anxiety properties or cell protection. ${ }^{2}$ Taurine is used in medicinal products exclusively in the context of so-called parenteral nutrition.

\section{Caffeine - physiological properties}

Caffeine is contained in many foods such as espresso, dark chocolate, coffee, cola, and energy drinks. It is colorless and odorless but tastes slightly bitter and is approved as a food additive E268. ${ }^{3}$ Caffeine has different effects on the human body. It acts as an antagonist to adenosine by occupying the receptors of the VLPO (ventrolateral preoptic area) and thus producing a sleep-suppressing effect. ${ }^{4}$

The interaction with adenosine disrupts memory and information can only be passed slowly from cell to cell. People get tired and their concentration drops. This feedback process protects the human body from possible overexertion. Since caffeine molecules are built similarly to adenosine molecules, they can displace them and accelerate the flow of information from cell to cell, which increases concentration and alertness again. However, consuming caffeine too often leads to increased adenosine production, which means that more and more caffeine is needed to achieve the same effect. Caffeine affects the nervous system in two ways. It inhibits the enzyme that converts the intracellular messenger substance cAMP (cyclic adenosine monophosphate) into AMP. The inhibition of the enzyme, the cAMP-specific phosphodiesterase, leads to an increase in the concentration of cAMP in the corresponding cells. ${ }^{5}$

Caffeine is one of the most widely consumed products in the world and appears to interact with several components of the immune system by acting as a non-specific phosphodiesterase inhibitor. ${ }^{6}$ 


\section{Taurine and caffeine as ingredients in energy drinks}

The term "energy drink" is a collective term for drinks that have a stimulating effect on the organism and are intended to provide energy. With their increased caffeine content, they are said to act against tiredness, weakness or a lack of concentration. According to surveys by the European Food Safety Authority (EFSA), around 60 percent of young German people between the ages of 10 and 18 consume energy drinks, 37 percent drink energy drinks in combination with alcohol. However, with the consumption of three or more doses in a row, they exceed the amount of caffeine regarded as harmless. These products are suspected of causing irregular heartbeat, seizures, kidney failure, or even death. However, the consequences of chronic, high-dose consumption of energy drinks in adolescents have not yet been scientifically examined.7

Many energy drinks contain caffeine and taurine in combination. The content in an energy drink has been regulated by law since June 2, 2013. According to the Fruit Juice and Soft Drinks Ordinance, it is a caffeinated soft drink and may contain a maximum of $320 \mathrm{mg}$ of caffeine per liter and $4000 \mathrm{mg}$ of taurine per liter. ${ }^{8}$

Almost all energy drinks contain caffeine. The maximum concentration of caffeine in the blood is reached about 30 to 45 minutes after consumption. The decomposition time in adults is about 3 to 5 hours, the substance is passed on through the body's own fluids and finally excreted in the urine. The average half-life period of caffeine in the body is around four hours. ${ }^{9}$

If a person is given a portion of energy drink or coffee with caffeine in an amount of 7,2 $\mathrm{mg} / \mathrm{kg}$ body weight, the serum concentration 45 minutes after administration reaches the highest value of $12,4 \mu \mathrm{g} / \mathrm{ml}(+/-1,5 \mu \mathrm{g})$. This amount is comparatively high. Therefore, the B-cells are exposed to different caffeine concentrations in the test series: 40;150;400 and $4000 \mu \mathrm{g} / \mathrm{ml} .^{10}$ The serum concentration of taurine in a healthy adult is about 50,78 $\mu \mathrm{mol} / \mathrm{l}(+/-5,25)$. This corresponds to an amount of $0.00635 \mathrm{mg} / \mathrm{ml}$. In organs, however, the taurine content is considerably higher and is between 190 and $1324 \mathrm{mg} / \mathrm{kg}$. In order to cope with the increased taurine content in the organ system after the consumption of energy drinks, B-cells are exposed to the following taurine concentrations: $0.4 ; 1.5 ; 4$ and $40 \mathrm{mg} / \mathrm{ml} .11$

\section{B-lymphocytes and antibodies}

The most important immunologically active cells are the lymphocytes (B- and T-cells) and the phagocytes. B-cells represent the core of the humoral or antibody-mediated defense. It takes place through the body fluids of the blood or the lymph. The antibodies are made by B-lymphocytes, immunologically active white blood cells. After contact with an antigen, B-cells differentiate into antibody secreting plasma cells. Since all B-cells of one type are the result of cloning, they also produce the same type of antibody. If T-helper cells were characterized by the same peptides during an infection with macrophages, they can stimulate B-cells to form specific antibodies against the envelope protein. ${ }^{12}$ T-effector cells activate B-cells and ensure that resting B-cells enter the cell cycle. One such molecule is the CD40 ligand, for which the B-cell carries a corresponding receptor. Interleukin-4 (IL-4), which is a peptide hormone and one of the messenger substances of the immune system, is also involved. Binding to CD40, together with IL-4, leads to the growth and 
multiplication of B-cells. Therefore, these two factors are added during the experimental incubation of B cells. ${ }^{12,13,14}$

\section{Methods}

The method of experiment used in this thesis was developed by Miltenyi Biotec. This method is used to answer the following research question: "How high is the effect of the combination of caffeine and taurine of different concentrations on activated B-cells?". Two reagents are used for experiment. In the first step, the existing cell suspension is incubated with so-called "MACS Micro Beads". These are 50nm small magnetic particles that are coupled to specific antibodies. These antibodies act against surface structures of the cells which should be selected. These particles are so small that they do not affect other cell structures. In the next step, a separation column is used, on which a strong magnetic field act. The cells labeled with the Micro Beads are held back by this magnetic field. The structure of the column ensures that all other cells can flow through. ${ }^{15}$

To harvest the cells, mice are killed by adding carbon dioxide gas. The spleen is then removed from the mouse and a cell suspension made in PBS buffer (phosphate buffered saline). The number of cells obtained depends on the age and condition of the mice and is about $10^{8}$ cells. The magnetic cell separation used here is based on the principle of negative selection. All cells except the B-cells are magnetically marked. A cocktail of biotin-bound antibodies against CD43 and CD4 is used for this. The determination of the cell number results in approx. $1510^{6}$ cells. ${ }^{16,17}$

\section{Immunoglobulin Isotype Assay = ELISA}

The immunoglobulin isotype assay is an antibody-based detection method. For this purpose, the antigen to be examined is fixed on the bottom of a microtiter plate. The bottom is coated with antibodies that act against the antigen in question. After this fixation, an antibody is added that binds to the antigen. An enzyme is bound to this antibody, which reacts with a dye and shows a positive signal. As a rule, the marker enzyme horseradish peroxidase (HRP = horseradish peroxidase) is bound to this secondary antibody. After activation by the enzyme, the dye 3,3,5,5-tetramethylbenzidine (TMB) is blue (absorption at 650nm). Since this dye is photosensitive, sulfuric acid is added, which turns TMB yellow. This absorption can be measured in the photometer at $450 \mathrm{~nm}$. With the use of a secondary antibody, this method is also known as an indirect ELISA method. 18

The ELISA kit from BD-Pharmingen is used for this. The advantage of this method is that the microtiter plate does not have to be coated beforehand in a special step. This gives quick, yet meaningful results. ${ }^{19}$ 


\section{Results}

Assuming an average half-life of 4 hours for caffeine, the caffeine level in the blood plasma drops to around $6.75 \% 16$ hours after ingestion. Therefore, cells are incubated with caffeine for 16 hours. To investigate long-term effects (see permanent consumers), the cells are also exposed to these concentrations for 96 hours. These test conditions apply to the following tests in combination with taurine since no half-life can be determined for the conversion of taurine in the body. In each of these cases, Igproduction was examined by means of ELISA. For the 16-hour as well as for the 96-hour experiment, three test series were carried out and the results were documented. During the experiment, the positive control was always measured at the same time. The values presented are the measured values of absorbances at $450 \mathrm{~nm}$ relative to the positive control.

\section{$16 h$ incubation period}

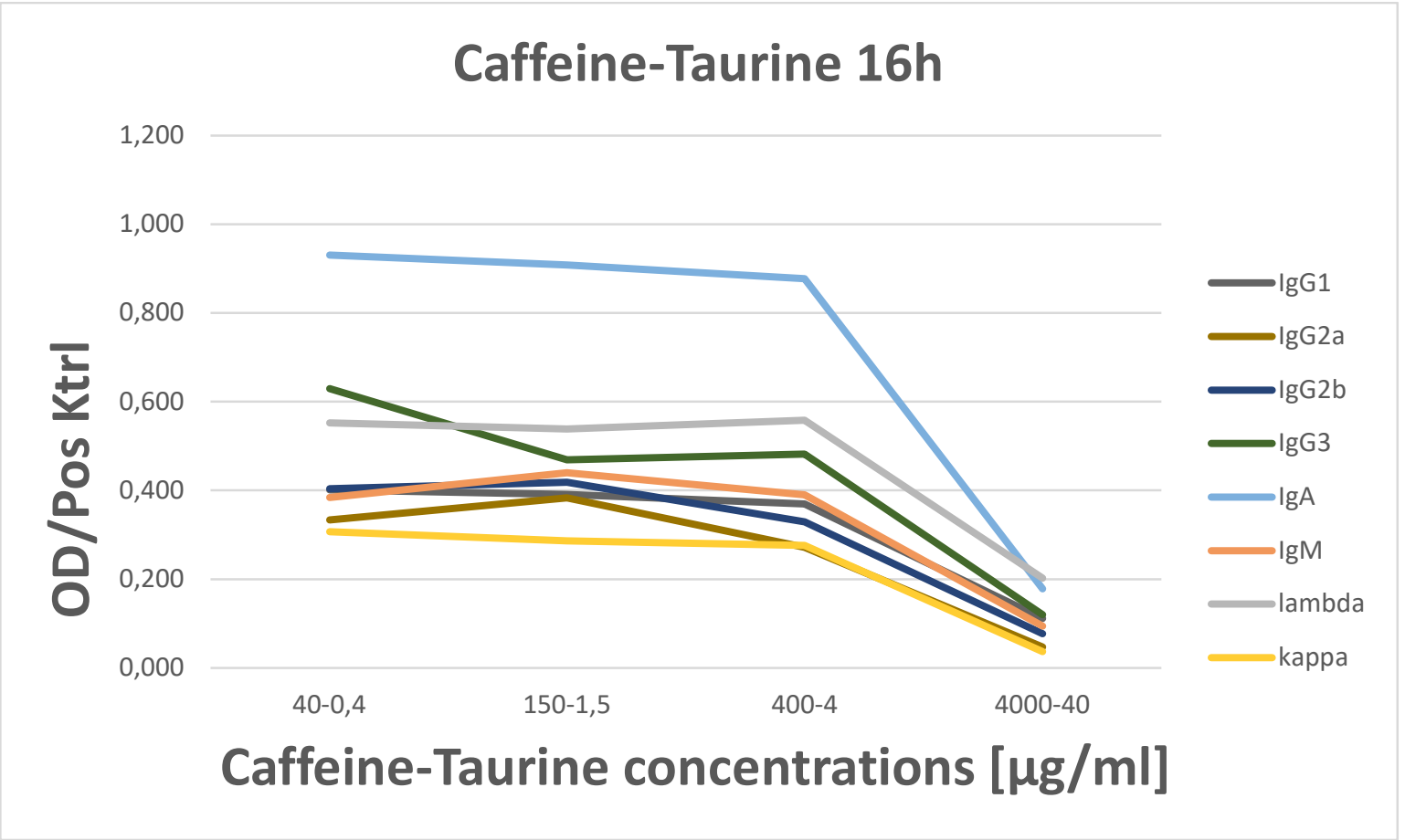

Figure 1: Mouse Ig ELISA with caffeine-taurine concentrations and 16h incubation

The 16-hour incubation shows that high concentrations of the two ingredients inhibit the activity of the B cells. A largely stable antibody production can be observed in the range of low and medium concentration. The exception is IgG3 and, here, the activity drops more clearly at the beginning. 
96h incubation period

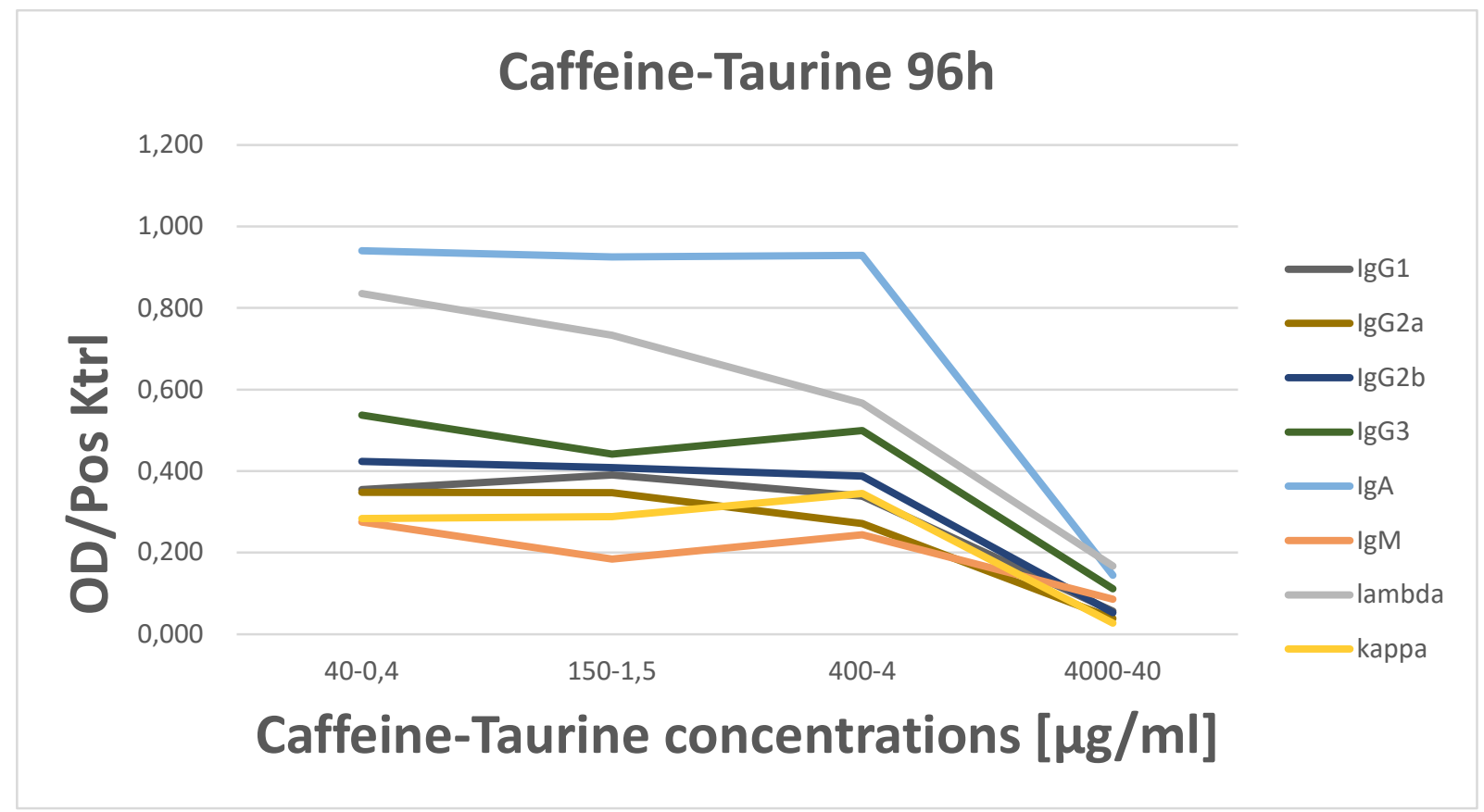

Figure 2: Mouse Ig ELISA with caffeine-taurine concentrations and 96h incubation

After 96 hours, the results are largely confirmed. Here, too, the activity remains almost constant up to a caffeine and taurine concentration of 400 and $4 \mu \mathrm{g} / \mathrm{ml}$, respectively. However, a decline in activity can also be observed here with IgG3. In addition, high concentrations have an inhibiting effect. 


\section{Evaluation and Conclusion}

Manufacturers of energy drinks invest hundreds of millions of euros every year in advertising trendy and risky sports. In addition, the question arises whether the immune system, and especially B cells, benefit from it. Physiological concentrations up to the empirical solubility limit were examined. However, it must be considered that these cells were activated with factors CD40 and IL-4. The experiments were carried out outside of an organism, but with activated B cells. It can therefore be assumed that their activity in the living system is still somewhat lower. Overall, the results show almost identical results after 16 hours and after 96 hours of incubation. Basically, based on these measurement results, it can be concluded that the intake of caffeine and taurine, as consumed with energy drinks, has little effect on B-cells. The only exception here is the effect of high dosages. A strong decline in activity can be observed here from a concentration of 4000 $\mu \mathrm{g} / \mathrm{ml}$ caffeine and $40 \mu \mathrm{g} / \mathrm{ml}$ taurine. Such a concentration close to the solubility limit is hardly reached in the blood plasma under natural circumstances. A negative effect on Bcell activity is therefore not to be expected with normal consumer behavior. However, this is just as unjustifiable as a motivation for nutritional supplementation. 


\section{References}

1. Bulley S, Liu Y, Ripps H, Shen W: Taurine activates delayed rectifier Kv channels via a metabotropic pathway in retinal neurons; L Physiol. 2013 Jan 1;591(Pt 1):123-32. doi: 10.1113/jphysiol.2012.243147. Epub 2012 Oct 8.

2. R J Huxtable: Physiological actions of taurine; Physiol Rev . 1992 Jan;72(1):101-63. doi: 10.1152/physrev.1992.72.1.101.

3. U.S. National Library of Medicine: ChemIDplus A Toxnet Database.

4. Leonard TK, Watson RR, Mohs ME: The effects of caffeine on various body systems: a review: Journal of the American Dietetic Association 1987, 87(8):1048-1053.

5. Elmenhorst D1, Meyer PT, Matusch A, Winz OH, Bauer A: Caffeine occupancy of human cerebral A1 adenosine receptors: in vivo quantification with 18F-CPFPX and PET: J Nucl Med. 2012 Nov;53(11):1723-9. doi: 10.2967/jnumed.112.105114. Epub 2012 Sep 10.

6. John A. Sturman: Kenneth C. Haye: The Biology of Taurine in Nutrition and Development; ; Advances in Nutritional Research pp 231-299.

7. European Food Safety Authority: "Energy" drinks report; https://www.efsa.europa.eu/en/press/news/130306.

8. Bundesministerium der Justiz und für Verbraucherschutz: Verordnung über Fruchtsaft, Fruchtnektar, koffeinhaltige Erfrischungsgetränke und Kräuter- und Früchtetee für Säuglinge und Kleinkinder (Fruchtsaft- und Erfrischungsgetränkeund Teeverordnung - FrSaftErfrischGetrTeeV); https://www.gesetze-iminternet.de/frsaftv_2004/BJNR101600004.html.

9. Wang T, Kleber G, Stellaard F, Paumgartner G.: Caffeine elimination: A test of liver function: Klin Wochenschr. 1985 Nov 4;63(21):1124-8.

10. Gong H Jr, Simmons MS, Tashkin DP, Hui KK, Lee EY: Bronchodilator effects of caffeine in coffee. A doseresponse study of asthmatic subjects: Chest. 1986 Mar 89(3):335-42.

11. Ibraheem M. A. EL Agouza and Dalia E. EL Nashar: Serum Taurine as a Marker of Endometrial Cancer: The Open Women's Health Journal, 2011, 5, 1-6.

12. Charles A. Janeway, Paul Travers, Mark Walport, Mark Shlomchik: Immunbiologie: Spektrum Akademischer Verlag, 5. Auflage, 2002: 42, 372-405, 417-428.

13. Rush JS, Hodgkin PD: B cells activated via CD40 and IL-4 undergo a division burst but require continued stimulation to maintain division, survival and differentiation: Eur J Immunol. 2001 Apr;31(4):1150-9.

14. James S. Rush, Philip D. Hodgkin: B cells activated via CD40 and IL-4 undergo a division burst but require continued stimulation to maintain division, survival and differentiation: European Journal of Immunology Volume 31, Issue 4, April 2001, 1150-1159.

15. M. Zborowski, J.J. Chalmers: Magnetic cell seperation, Elsevier B.V. 2008.

16. Herstellerangaben: B Cell Isolation Kit, Order no. 130-090-862, Miltenyi Biotec Inc.

17. Gerhard Gstraunthaler, Toni Lindl: Zell- und Gewebekultur: Allgemeine Grundlagen und spezielle Anwendungen; Springer Pektrum Verlag 7., überarb. u. erg. Aufl. 2013, XIII-

18. Eva Engvall, Peter Perlmann: Enzyme-Linked Immunosorbent Assay, Elisa, Quantitation of Specific Antibodies by Enzyme-Labeled Anti-Immunoglobulin in Antigen-Coated Tubes, The Journal of Immunology July 1, 1972-

19. Herstellerangaben: Mouse Immunoglobulin Isotyping ELISA Kit, Technical Data Sheet, Material Number 550487, BD Pharmingen. 


\section{Note of thanks:}

Special thanks go to Prof. Straub and his working group on Innere Medizin I at the University of Regensburg for the opportunity to carry out this work and for the always helpful support.

\section{Attachments}

\section{List of Abbreviations}

\begin{tabular}{|l|l|}
\hline CD & Clusters of Differentiation \\
ELISA & Enzyme-linked immune absorption test \\
HRP & horseradish peroxidase \\
IL & Interleukin \\
OD & Optical density (Extinktion) \\
TMB & $3,3,5,5$-tetramethylbenzidine \\
\hline
\end{tabular}

\section{List of tables}

Figure 1: Mouse Ig ELISA with caffeine-taurine concentrations and 16h incubation

Figure 2: Mouse Ig ELISA with caffeine-taurine concentrations and 96h incubation

\section{Statistics}

The following tables are the mean values that have already been shown as figures. These are not individual measurements, but mean values from series of measurements. 
Mouse Ig ELISA with caffeine-taurine concentrations and 16h incubation:

\begin{tabular}{|l|c|c|c|c|c|c|c|c|}
\hline Average & IgG1 & IgG2a & IgG2b & IgG3 & IgA & IgM & lambda & kappa \\
\hline $40-0,4$ & 0,402 & 0,333 & 0,404 & 0,630 & 0,931 & 0,384 & 0,552 & 0,307 \\
\hline $150-1,5$ & 0,391 & 0,384 & 0,419 & 0,469 & 0,908 & 0,440 & 0,538 & 0,286 \\
\hline $400-4$ & 0,369 & 0,272 & 0,329 & 0,482 & 0,877 & 0,390 & 0,559 & 0,276 \\
\hline $4000-40$ & 0,112 & 0,047 & 0,078 & 0,120 & 0,178 & 0,095 & 0,202 & 0,037 \\
\hline $\begin{array}{l}\text { Standard } \\
\text { deviation }\end{array}$ & & & & & & & & \\
\hline $40-0,4$ & 0,323 & 0,181 & 0,244 & 0,264 & 0,020 & 0,219 & 0,056 & 0,100 \\
\hline $150-1,5$ & 0,324 & 0,184 & 0,227 & 0,230 & 0,099 & 0,090 & 0,024 & 0,108 \\
\hline $400-4$ & 0,326 & 0,203 & 0,248 & 0,304 & 0,092 & 0,119 & 0,105 & 0,141 \\
\hline $4000-40$ & 0,121 & 0,035 & 0,075 & 0,114 & 0,098 & 0,081 & 0,097 & 0,028 \\
\hline
\end{tabular}

Mouse Ig ELISA with caffeine-taurine concentrations and 96h incubation:

\begin{tabular}{|l|c|c|c|c|c|c|c|c|}
\hline Average & IgG1 & IgG2a & IgG2b & IgG3 & IgA & IgM & lambda & kappa \\
\hline $40-0,4$ & 0,354 & 0,348 & 0,424 & 0,537 & 0,941 & 0,275 & 0,836 & 0,283 \\
\hline $150-1,5$ & 0,391 & 0,347 & 0,408 & 0,442 & 0,926 & 0,185 & 0,733 & 0,288 \\
\hline $400-4$ & 0,338 & 0,271 & 0,387 & 0,499 & 0,929 & 0,243 & 0,566 & 0,345 \\
\hline $4000-40$ & 0,057 & 0,039 & 0,053 & 0,111 & 0,145 & 0,086 & 0,167 & 0,027 \\
\hline $\begin{array}{l}\text { Standard } \\
\text { deviation }\end{array}$ & & & & & & & & \\
\hline $40-0,4$ & 0,254 & 0,207 & 0,226 & 0,198 & 0,066 & 0,082 & 0,016 & 0,062 \\
\hline $150-1,5$ & 1,019 & 0,222 & 0,175 & 0,214 & 0,104 & 0,124 & 0,286 & 0,039 \\
\hline $400-4$ & 0,259 & 0,132 & 0,156 & 0,184 & 0,026 & 0,083 & 0,004 & 0,020 \\
\hline $4000-40$ & 0,047 & 0,019 & 0,044 & 0,079 & 0,058 & 0,026 & 0,072 & 0,013 \\
\hline
\end{tabular}

